\title{
Prophecy and the prophetic as aspects of Paul's theology
}

\author{
Albert Hogeterp \\ University of the Free State, Bloemfontein, South Africa \\ alahogeterp@gmail.com
}

\begin{abstract}
As the earliest documents of Christianity, Paul's Letters include extensive evidence on prophecy and the prophetic, most particularly in 1 Corinthians $12-14$. In view of the influential hypothesis on "the cessation of prophecy" in Ancient Judaism on the one hand and early Jewish and Christian versatility on prophecy on the other, this essay addresses the question what prophecy meant in Paul's days and how it may be situated as a spiritual gift in Paul's theology. It reconsiders the cessation hypothesis vis-à-vis Early Judaism, providing caveats on its application to the Dead Sea Scrolls and Flavius Josephus, thereby redressing the Second Temple Jewish context of Christian origins in this respect. The essay provides a contextual reading of key passages (1 Cor 12:411, 13:8-13, 14:1-5, 14:20-33a), offering new insights about communal parameters of prophecy by comparing Paul's ideas with contexts of Judaism, Jewish Hellenism and the Corinthians' Greek environment.
\end{abstract}

Key words

Prophecy; cessation hypothesis; Paul; 1 Corinthians 12-14

\section{Introduction}

Biblical prophecy is central to Paul's concept of the gospel of God (Rom 1:2), ${ }^{1}$ and the Prophets, in particular Isaiah, are among the most prominently

1 Cf. Fitzmyer 1993: 233 on "prophets" in Romans 1:2 as a "generic expression" not specifying any OT prophets, yet "stemming from the God of the OT"; Dunn 1988: 10

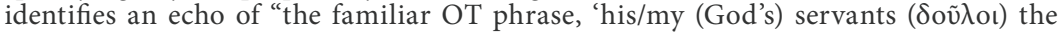
prophets" in Rom 1:2. See also Schnelle 2005: 404; Wolter 2011: 58-9. The plural ai ypapai also occurs in Rom 15:4, where its meaning as "scriptures", i.e. Old Testament, is substantiated by a preceding biblical quotation from Ps 69:9 in Rom 15:3. Quotations from individual books of biblical Prophets may also be introduced by, among other 
quoted Scriptures in Paul's Letters. ${ }^{2}$ The prophets of Israel are known from biblical literature and its early reception history as those sent by God, as

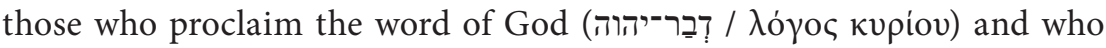
interpret Israel's history and destiny. ${ }^{3}$ The prophetic communication of the word of God could take various shapes of verbal or symbolic performance, in word and deed, through oracles (e.g. Isaiah), but also through powerful

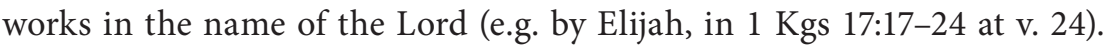
In Paul's theology, the category of prophecy does not only refer to the biblical "prophets of old" and the interpretation and fulfilment of their prophecies. In addition, the "prophetic" also plays a part in the apostle's thought about the workings and structure of the congregations in Christ. In Paul's Letters, and in particular in 1 Corinthians, prophecy as an early Christian phenomenon is understood as a divinely appointed speech act which addresses people in the interest of edifying the church (1 Cor 12:28, 14:1-5.29.31-33a). As such, early Christian prophecy counts among spiritual gifts (Rom 12:6-8; 1 Cor 12:10, 14:1) ${ }^{4}$ and prophets rank second to apostles in Paul's view of the church (1 Cor 12:28).

Yet in view of all this Pauline versatility regarding prophecy, the question is how we should read prophecy and the prophetic in Paul's Letters contextually. That is, discussions of the broader contexts of Early Judaism and emerging Christianity diverge remarkably on the Nachleben of the biblical tradition of prophecy and its significance in the Second Temple period. On the one hand, scholarship regarding the alleged "cessation of prophecy" in early Judaism emphasizes the discontinuity in succession of

introductory formulae, $\lambda \dot{\varepsilon} \gamma \varepsilon ı \dot{\eta} \gamma \rho \alpha \varphi \eta \dot{~(R o m ~ 10: 11) . ~ I t ~ t h u s ~ s t a n d s ~ t o ~ r e a s o n ~ t h a t ~ P a u l ~}$ has nothing else than biblical prophecy in mind with his clause o̊ $\pi \rho \circ \pi \eta \eta \gamma \gamma \varepsilon \dot{\imath} \lambda \alpha \tau$ o $\delta$ ı̀̀

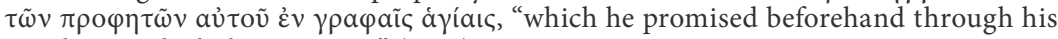
prophets in the holy scriptures" (RSV) in Romans 1:2.

2 Cf. Wilk 1998; Wilk 2005: 133, "certain sections of Isaiah have significantly shaped Paul's self-understanding and his theology", who designates theological vocabulary, phraseology and motifs from Isaiah as "the background of several Pauline concepts".

3 Cf. Cook 2011: 90 n.166 on the distinct role of the biblical prophet "as interpreter of Israel's history and as promulgator of the will of God on a national scale"; Nissinen 2016: 5-6 on the principal function of prophecy in ancient sources and societies as "(inter)mediation of divine knowledge" with four essential components: sender, message, prophet and recipient(s).

4 As such, prophecy as a spiritual gift and as a ministry/office in Pauline congregations is the object of varying attention in major theologies of Paul by Dunn 1998: 556-8, 580-2; Schnelle 2005: 571-2; Wolter 2011: 154, 198-201, 267; Sanders 2015: 275-9. 
biblical prophets since the time of Ezra onwards, and the lack of evidence for the appearance of prophets in later times. ${ }^{5}$ On the other hand, the study of emerging Christianity points to evidence of a prolific prophetism, that is, a variety of prophetic characters (Mk 6:15; Lk 7:16.26; Mt 11:1314; Acts 11:27, 13:1, 15:32, 21:9.10), functions (e.g. Mk 9;9-13; Lk 7:11-17), and authority (cf. Mk 11:32), as well as prophetic expectations related to the early Jesus-movement as illustrated in the Gospels and Acts. ${ }^{6}$ The question of context is an important issue here. The workings and reception of prophecy are not only determined by a process of sender, message, prophet, and recipients in the immediate literary setting of a text. A larger communal setting also plays a pivotal role in understanding prophecy. ${ }^{7}$ Therefore, a broader contextual reading of prophecy and the prophetic in Paul's Letters in light of early Jewish, Greco-Roman and earliest Christian contexts may help to situate its communal parameters. So far scholarship has focused much attention on the prophetic self-understanding of Paul as apostle, ${ }^{8}$ and on intertextuality with prophetic literature, in particular Isaiah. ${ }^{9}$ Since prophecy is particularly prominent among spiritual gifts in Paul's first Letter to the Cor 12-14, my article will focus on close reading of relevant sections and aim to correlate this with a broader contextual reading.

My contextual reading of relevant sections in 1Cor 12-14 will aim to answer the following questions:

5 Cook 2011: 5-9 cites the following evidence for the traditional view of the lack of prophecy/prophets: Hebrew Bible (Amos 8:11; Mic 3:6-7; Isa 63:11; Ps 74:9; Lam 2:9; Zech 13:2-3), OT Apocrypha (1 Macc 4.45b-46, 9.27, 14.41; PrAzar 15), Dead Sea Scrolls (1QS 9.9-11; 1QpHab 2.6-10, 7.4-5), OT Pseudepigrapha (2 Baruch 85.1-3), New Testament (Mt 11:13; Mk 6:15; Jn 8:52; Acts 19:2; Heb 1:1-2), Josephus (Ag. Ap. 1.41), patristic literature and rabbinic literature.

6 For prolific activity of early Christian prophets, see Acts 11:27, 13:1, 15:32, 21:9.10; horizons of expectation of fulfilment of prophecy, the return of prophets, and restoration abound in the Gospels and Acts (cf. Mk 6:14-16, 8:27-30, 9:9-13; Lk 1:76, 7:16, 24:19; Acts 2:14-36, 3:12-26. On early Christian prophecy and prophetism, see studies by Aune 1983; Luz 2010.

7 See Nissinen 2016: 5, "the prophetic performance has to be acknowledged by a community that ultimately decides whether or not it was to be appreciated as transmitting a divine word", and 6, who further refers to studies by De Jong 2007: 31; Stökl 2012: 7-11; Weippert 2014: 231-2 regarding the definition of prophecy.

8 Sandnes 1991; Merklein 1998; Nicklas 2010.

9 Wilk 1998 and 2005. 
1. how does the arguable divide between an alleged "cessation of prophecy" in Early Judaism, a traditional view as recently formulated by L.S. Cook (2011), and a prolific prophetism in emerging Christianity, as noted above, impact the understanding of prophecy in Paul's Corinthian correspondence?

2. Which sense of "prophecy" does Paul have in mind in his discussion of spiritual gifts (1 Cor 12-14) and how does this relate to ideas about prophecy at the time?

3. What does prophetic performance do in the communal setting of the Corinthian audience, as inferred from 1 Cor 12-14?

It is the working hypothesis of this article that the imagined worlds of Judaism, Jewish Hellenism, the larger missionary Jesus-movement, and the Greek environment all mattered to Paul's Corinthian audience in greater or lesser degrees, in regard to his apostolic instructions and theological discourses. ${ }^{10}$ Some examples may suffice here to explain that these imagined worlds play a part in Paul's epistolary communication with his Corinthian audience. In 1 Cor 10:1-13, Israel's biblical past is invoked by Paul, who gives a typological interpretation of the biblical narrative on Israel's wanderings in the wilderness ${ }^{11}$ for instruction against the Corinthians' overconfidence in face of temptations to idol worship. This issue of idol worship is reiterated at the beginning of 1 Corr 12. Just before considering spiritual gifts, among which is prophecy, Paul warns the Corinthian audience against pagan backgrounds of idolatry amongst themselves (1 Cor 12:1-3). ${ }^{12}$ And in 1 Cor

10 This working hypothesis also finds support in the characterization of Roman Corinth at the time of Paul in various commentaries, with attention for the interconnected missionary Jesus-movement in relation to the Jerusalem church, Greeks, Roman colonists, Jews, and resident aliens by Fitzmyer 2008: 30-36 at 31; Barrett 1968: 20-1 on "Judaism and Other Religions" in Corinth; Conzelmann 1975: 11-12 on "The Milieu: the City of Corinth"; Perkins 2012: 16-18 on Corinth, Jewish confrontation with Paul and proconsul Gallio in Acts 18; and Fee 2014: 1-4 on religious diversity in Corinth, comprising 26 sacred places (Pausanias) as well as a Jewish synagogue, and on the diversity of Paul's Corinthian audience, consisting of Jews, Greeks, Romans, freedman and slaves.

11 Exodus 32:6 is explicitly cited in 1 Cor 10:7. Cf. Hogeterp 2006: 356. See Fitzmyer 2008: 379 on intertextuality with Numbers (LXX Num 11:4.34-35, 14:20-35, 21:4-9 and 25:1-9).

12 Pagan backgrounds refer to non-Jewish, polytheistic contexts in Corinth, which was the presumable background of an arguably greater or lesser part of Paul's Corinthian 
10:32, Jews, Greeks and the church of God are all considered as social groups, ${ }^{13}$ to whom the Corinthians should give no offense (cf. 1 Cor 9:19-23), in the interest of the congregation's good standing in society. ${ }^{14}$ The larger context of the missionary Jesus-movement, including the Jerusalem church, is evoked by Paul's references to the Corinthians' part in a contribution for the saints and to their gift for Jerusalem in 1 Cor 16:1-3. Therefore, Judaism and Jewish Hellenism, ${ }^{15}$ the early church and the Greek environment are all contexts which need to be taken into account in the study of prophecy and the prophetic as aspects of Paul's theology in 1 Cor 12-14.

The outline of the structure of this essay is as follows. I will consecutively highlight:

1. prophecy in biblical and early Jewish tradition, focusing on the traditional "cessation" hypothesis, as synthesized and recently formulated by L.S. Cook in 2011 (see note 5 and the first question to be answered above);

2. the prolific evidence for prophecy in emerging Christianity;

3. prophecy in Paul's Letters at large;

4. contextual readings in 1 Cor $12-14$, taking into account aspects of the Corinthians' Greek environment that may touch upon the understanding of spiritual gifts and the place of prophecy among them.

audience; cf. e.g. Barrett 1968: 278 on 1 Cor 12:2 as concerning "many, though not all, of the Corinthian Christians (having been) non-Jews; cf. Acts 18: 5, 6, 8"; Fitzmyer 2008: 457 on 1 Cor 12:2 as Paul's reaction to "Corinthian Christians of pagan background"; Perkins 2012: 147 on 1 Cor 12:2 as the "Corinthians' past as idol worshipers".

13 Cf. Barrett 1968: 244-5 on 1 Cor 10:32 as referring to three groups, Jews, Greeks and Christians, of which the latter is seldom added by Paul; Fitzmyer 2008: 403 on 1Cor 10:32 as concerning "three groups of humanity (Jews, Gentiles, and Christians)"; Fee 2014: 538 on 1 Cor 10:32 as relating to "Jews, nonbeliever, or fellow believer".

14 Cf. Perkins 2012: 129 on 1 Cor 10:32 as Paul's reaction against "Corinthian tendencies toward making distinctions between believers", in comparison with 1 Cor 9:19-23 as relating to Jews and non-Jew alike. See also Thiselton 2000: "The categorization (with каi) of Jews, Gentiles, and the Church of God, all alike, looks back to Paul's personal examples in 9:19-23".

15 Cf. Levinskaya 1996: 162-6 on epigraphic and literary evidence for a Jewish community in Roman Corinth; Hogeterp 2006: 305-9 on Judaism as a surrounding culture to the Corinthian congregation. 
In my evaluation and conclusions, I aim to answer questions on the communal settings of prophecy in 1 Cor 12-14 against the broader contexts noted above.

\section{Contexts of prophecy in Biblical and early Jewish tradition}

\subsection{Biblical Prophecy and the "Cessation" hypothesis}

The phenomenon of prophecy has a longstanding background in the Hebrew Bible and the ancient Near East, ${ }^{16}$ where oracles of salvation as well as of doom could be mediated as divine messages by prophetic figures to individuals or groups. Yet in the traditional view of biblical prophecy, the "classical prophecy" of Israel is seen as belonging to the monarchical period, followed by a decline in the post-exilic period. ${ }^{17}$ This traditional view still leaves the question open to debate how prophecy was perceived in the Second Temple period, during which Paul also wrote his Letters, and which arguable role it would then play in the Jewish settings from which Christianity emerged.

The question of the so-called "cessation of prophecy" in early Second Temple Judaism, during the Persian period, has recently been addressed by L. Stephen Cook, who concluded that "Second Temple Jews did, on the whole, tend to believe that prophecy had ceased in the Persian period". ${ }^{18}$ Cook thereby did not deny revelatory phenomena, religious enthusiasm, and spiritual fervour a place in Second Temple Judaism, but he considers them in discontinuity with biblical prophecy. In this line of thought, early Christian prophetism would constitute a return of prophecy as a phenomenon of inspired mediation of a divine message rather than a direct continuation of prophecy from the Hebrew Bible onwards into the time of Jesus.

16 For literature on this subject, see the books by De Jong 2007; Stökl 2012; Weippert 2014.

17 Floyd 2006: 1; Cook 2011: 3; note the time frame for comparative study of prophecy in the Hebrew Bible "until the beginning of the Persian period at the end of the sixth century," as used by Stökl 2012: 1. Cf. Lange 2005: 181-2 on Neh 6:1-14 as evidence of "the marginalization of prophecy in Persian times", who further argues for a decline of "aural prophecy" and the ascent of "literary prophecy" evidenced in the Scrolls.

18 Cook 2011: 192. 
In studies since the 1990s, various types of discontinuity have further been noted with regard to prophecy, not so much in terms of "cessation" but of transition. The following types of transition have been suggested in previous scholarship regarding the Second Temple period:

- from prophecy to exegesis or inspired interpretation ${ }^{19}$

- from oracular modes of prophecy to textualized and sapiential settings of revelation ${ }^{20}$

In these scholarly views, a disjunction with as well as elaborations on the prophetic heritage of ancient Israel may tentatively be discerned in Second Temple Judaism.

Since Paul wrote his Letters by the time of the late Second Temple period, I will now turn to early Jewish ideas about prophecy in order to highlight contexts of thought about prophecy in ancient Judaism preceding and contemporaneous with emerging Christianity.

\subsection{Early Jewish ideas about prophecy}

Before turning to some salient examples of texts regarding ideas of prophecy vis-à-vis the "cessation" hypothesis, certain commonalities across early Jewish literature regarding prophecy are to be noted at the outset. Next to being sent by God to proclaim the word of God, the following features of prophecy recur across the works of various authors of early Jewish literature:

1. its empowerment through God's Spirit; ${ }^{21}$

2. its trustworthiness as true and evident knowledge; ${ }^{22}$

3. its infallible capacity to foretell future events ${ }^{23}$

19 Schniedewind 1995.

20 Jassen 2007 and 2016.

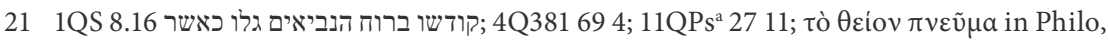
QG 3.9, Her. 265, Spec. Laws 4.49; Josephus, Ant. 8.408.

22 Sir 36.21, 46.15; Philo, QG 3.9; Josephus, Ant. 8.418.

23 Tob 14.4-5 // 4Q198 (4QTob ${ }^{c}$ ar) 1 4-6 and 12; Philo, Her. 261; Josephus, Ant. 8.418. Feldman [1990: 409] 2005: 229, thus distinguished the Essenes, who "seldom, if ever, (..) err in their predictions", as described by Josephus, J.W. 2.159, from prophets, who "would never err". 
The texts to which this section now turns for illustration concern the Dead Sea Scrolls from Israel and the writings of Flavius Josephus as evidence of Jewish Hellenism.

\section{Dead Sea Scrolls}

The Dead Sea Scrolls roughly cover the time-span from the second century B.C.E. to the first century C.E. On the one hand, the scriptural status of prophets appears evident from a Qumran-type of commentary, the Pesharim on Isaiah (4QpIsa ${ }^{\mathrm{a}-\mathrm{e}}$ ) and five of the twelve Minor Prophets, Hosea (4QpHos $\left.{ }^{\mathrm{a}-\mathrm{b}}\right)$, Micah (1Q14, 4Q168), Nahum (4QpNah), Habbakuk (1QpHab), and Zephaniah (4QpZeph). On the other hand, parabiblical expansions on prophetic books, such as Pseudo-Ezekiel and the Apocryphon of Jeremiah from Qumran cave $4,{ }^{24}$ illustrate permeable textual boundaries in literary elaboration on the Prophets. Daniel, who was also considered a prophet (4Q174 $1 \mathrm{ii}+3+24+53$; Mt 24:15), is further surrounded by a Qumran Daniel cycle. ${ }^{25}$ Next to parabiblical elaboration, the fact that the canon was not yet fixed and a certain measure of textual fluidity surrounded even prophetic texts, such as Jeremiah, ${ }^{26}$ impacts the late Second Temple Jewish context to ideas about biblical prophecy. These literary matters are not considered in Cook's book on the "cessation of prophecy". ${ }^{27}$

Jewish Hellenism: Evidence from Josephus

As for Jewish Hellenism, we may briefly consider prophecy in Flavius Josephus, whose writings date to the end of the first century C.E., but look back to the Second Temple period. ${ }^{28}$

Crucial evidence for the "cessation" hypothesis regarding Josephus is his statement about the "failure of the exact succession of the prophets" from

24 4QpsEzek ${ }^{\mathrm{a}-\mathrm{e}}(4 \mathrm{Q} 385,386,385 \mathrm{~b}, 388,390)$; 4QapJer A-C ${ }^{\mathrm{f}}(4 \mathrm{Q} 383,385 \mathrm{a}, 387,388 \mathrm{a}, 389-$ 390, 387a).

25 4QprNab ar, 4QpsDan ${ }^{\mathrm{a}-\mathrm{c}}$ ar, 4Q246; cf. 4Q552-553a (4QFour Kingdoms ${ }^{\mathrm{a}-\mathrm{c}}$ ar).

26 Cf. Jassen 2016: 353.

27 As for the Scrolls, Cook 2011: 6, 79-82, only incorporates references to sectarian Qumran texts (CD-A; 1QS; 1QH ${ }^{\mathrm{a}}$; 1QpHab; 4Q174; 4QpPs ${ }^{\mathrm{a}}$ 4Q175; 11QMelch), all published and well-known long before the 1990s.

28 It is beyond the scope to survey prophecy in Philo of Alexandria here, but see on this the articles of N.G. Cohen and J.R. Levison in Floyd and Haak 2006: 166-93 and 194209. At any rate, Philo's concern with prophetic inspiration stands in the shadow of his overwhelming literary concern with the Pentateuch. 
the time of Artaxerxes onwards (Ag. Ap. 1.41). ${ }^{29}$ Upon the "cessation" hypothesis, there is a clear disjunction between the biblical prophets on the one hand and phenomena of prophetic inspiration as well as false claims to prophecy in the Second Temple period on the other in Josephus' works (cf. J.W. 2.261; Ant. 20.97, 20.169). ${ }^{30}$ Yet with regard to cessation, two caveats are in place.

First, one should carefully distinguish the end of the line of biblical prophets with the scriptural status of their writings from the ongoing phenomena of prophecy and prophetic inspiration in Josephus' works. Josephus attributes the gift of prophecy to John Hyrcanus (J.W. 1.68-69). Cook also surveys prophetic phenomena in Josephus. ${ }^{31}$ One should more accurately speak of the "cessation of the line of biblical prophets" than of the "cessation of prophecy" as phenomenon in Josephus' works.

A second caveat concerns the consideration of Josephus' works for evidence on "false prophecy". Perhaps 70 C.E. is not unimportant as terminus post quem for notions of "false prophecy". It may suffice to note the different perspectives on false prophets in, for instance, the Dead Sea Scrolls and Josephus respectively. For instance, an Aramaic "List of False Prophets" from Qumran (4Q339) only provides us a glimpse of false prophets in biblical Israel. ${ }^{32}$ Yet when Josephus speaks about Theudas and an Egyptian as false prophets, this is with a view to their roles as revolutionary leaders, of which the cause of war against Rome was definitely lost with the destruction of Jerusalem by 70 C.E. In fact, Josephus relates the cause of

29 Cf. Cook 2011: 8. On succession among biblical prophets, cf. LXX Sir 48.8 regarding

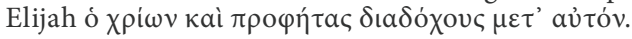

30 Feldman [1990] 2006: [386-422] 210-39; Cook 2011: 122-48. In Floyd and Haak 2006, an article by L.L. Grabbe (pp. 240-7) argues that for Josephus "prophecy definitely had not ceased" (247), but Cook 2011: 131 may be right that Grabbe overstates the case with his idea that Josephus saw himself as a "prophet".

31 Cook 2011: 136-44.

32 4Q339 (4QList of False Prophets ar) - קרא[ש] נביאי, enumerated as Balaam son of Beor (Num 24), the old man from Bethel (1 Kgs 13:11-18), Zedekiah son of Kenaanah (1 Kgs 22:24), Ahab son of Kolaiah (Jer 29:21), Zedekiah son of Maaseiah (Jer 29:21), Shemaiah the Nehelamite (Jer 29:31), Hananiah son of Azzur (Jer 28:1.5.10.11.12.13.15.17), further described as "the prophet from Gibeon" (Jer 28:1). Cf. Brooke 2006: 151-65 at 159-63 on 4Q375 14-5; CD-A VI 1-2; 1QH XII 16; 4Q267 2 6; 4Q269 4 i 2; 11QT ${ }^{a}$ LIV 8-18, LXI 1-5; 4Q339 (4QList of False Prophets ar) as references to false prophets. 
the Jewish war against Rome to a fatal misjudgement of prophetic oracles about rulership in the East (J.W. 6.312-313).

On a final note, the terminus post quem holds a fortiori for a post-70 C.E. writing such as 2 Baruch. Thus in 2 Baruch $85.1-3$, prophets and holy men are noted as interveners "in former times and former generations". Yet prophets are described as "sleeping" and the people are only left with the Mighty One and his Law, under the circumstance that "we have left our land, and Zion has been taken away from us" (2 Baruch 85.3). ${ }^{33}$ In other words, exile and destruction of Jerusalem - in the narrative setting as well as in the discursive setting of composition after 70 C.E. - predetermine the understanding of an active presence or dormant absence of prophets.

\section{Prophecy and prophetism in emerging Christianity}

The study of prophecy and prophetism in emerging Christianity yields a relatively divided picture. On the one hand, New Testament writings provide abundant indications of prophecy and prophets at the origins of Christianity. For instance, the Synoptic Gospels include popular ideas about Jesus as a prophet, like one of the prophets of old (Mk 6:15; cf. Lk 7:16) as well as about John the Baptist as a real prophet (Mk 11:32), next to the distinct expectation of restoration through the return of Elijah (Mk 9:9-13) supported by the scribes. Luke's infancy narrative further mentions Zechariah's act of prophesying who considers John as prophet of the Most High (Lk 1:67.76) and a prophetess Anna being present at the presentation of Jesus in the Jerusalem temple (Lk 2:36). According to the narrative of Acts, prophets, and among them Agabus, were part of the missionary Jesusmovement's contacts between Jerusalem and Antioch (Acts 11:27-28, 13:1, 15:32). In Acts 21:10-11, it is Agabus, who prophetically forewarns Paul about dangers involved in his return to Jerusalem. Beyond these examples from the Gospels and Acts, many more passages could be adduced to illustrate the existence of prophets and prophecy in the early church. ${ }^{34}$

33 Translation from Klijn 1983: 651.

34 Schnelle 2005: 571 noted Acts 15:32, 20:23, 21:4.10; Eph 3:5; 1 Tim 1:18, 4:14; Rev 11:18, 16:6, 18:24, 22:9 as evidence for early Christian prophets at work; Cook 2011: 7 ranks 1 Cor 12-14 among evidence for the existence of prophets/prophecy in the early church, along with Acts 11:27-28, 13:1; Eph 4:11; Rev 1:3, 18:20. 
Yet on the other hand, Christian prophecy was characterized by D.E. Aune as a "relatively unstable and unstructured institution within early Christianity". ${ }^{35}$ More recently, U. Luz situated a crisis of early Christian prophecy in the third generation of Christianity, by the end of the first century C.E., and related its ultimate marginalization. ${ }^{36}$ Cook has further argued that prophecy in the early church, including the Pauline evidence, is of a different nature than Old Testament prophecy, in that it "did not usually carry the same degree of authority as apostolic prescripts, not to mention OT prophecy or the teachings of Jesus". ${ }^{37} \mathrm{He}$ distinguished varying levels of quality and authority.

What then should we think about prophecy at the origins of emerging Christianity? In his comments on offices in the early church, U. Schnelle has taken the citation of Joel 3:1-2 about the outpouring of the Spirit applied to "the latter days" in Acts 2:17-18 as evidence for early Christian prophetic convictions. That is, the Jerusalem church was convinced that "the time of the cessation of prophecy was over and that the Spirit of God was now at work again". ${ }^{38}$ In other words, the eschatological fervour of the missionary Jesus movement carried with itself the early Christian conviction that the expected final age with prophetic agency had become inaugurated through Jesus Christ.

Another way of probing the significance of prophecy at the origins of emerging Christianity is to evaluate its role in Christianity's earliest documents, Paul's Letters, to which I will now turn.

35 Aune 1983: 231, at the same page: "Christian prophecy produced no distinctive speech forms which would have been readily identifiable as prophetic speech".

36 Luz 2010: 57-75. Cf. Tibbs 2007: 275, "In the second-century church, prophetic possession rapidly declined", and n. 3 with reference to J.L. Ash, "The Decline of Ecstatic Prophecy in the Early Church", TS 37 (1976) 227-52.

37 Cook 2011: 112-8 at 118.

38 Schnelle 2005: 571. 


\section{Prophecy in the Pauline letters}

\subsection{Biblical Prophecy in Paul's Letters}

In Paul's theology, promises about the Christ as Son of God from the line of David have been mediated beforehand "through his prophets in the holy scriptures" (Rom 1:2) and find their fulfilment in the gospel of God (Rom 1:1-6). As such, biblical prophecy precedes the apostleship as literary model (Rom 1:2-5). ${ }^{39}$ This ancient revealed word of God is to be carefully distinguished from early Christian prophecy, which in Paul's idea of emerging leadership in the church does not precede the apostleship, but comes after it (1 Cor 12:28).

Three biblical prophets are explicitly named by Paul: Elijah (Rom 11:2), Isaiah (Rom 9:27.29, 10:16.20, 15:12), and Hosea (Rom 9:25). All three figure in Paul's theological discourse on Israel in Romans 9-11. It is beyond the focus of this essay to consider intertextuality with biblical prophecy more broadly. Previous scholarship has recurrently pointed out intertextuality with biblical prophets in passages about Paul's calling and self-understanding as an apostle, such as in Romans 1:1-2 and Galatians 1:15-16. ${ }^{40}$ When I come to selected passages in 1 Cor $12-14$, I will further consider intertextuality in relevant cases. At any rate, in 1 Corinthians, Paul recurrently quotes from the book of Isaiah. ${ }^{41}$

Next to biblical prophecy, we need to consider settings of early Christian prophecy in Paul's Letters briefly, before turning to 1Corinthians, in particular to sections in 1 Cor 12-14.

39 See Sandnes 1991: 146-53 on Rom 1:1-5 as "Paul Standing on the Shoulders of the Prophets". Cf. Dunn 1988: 11 on Rom 1:2: “The prophets and prophecies in question would have been established as Christian proof texts as one of the earliest apologetic requirements of the new movement (cf. 1 Cor 15:3-4)".

40 Sandnes 1991: $48-70$ at 61 and 146-53 at 147-8; Nicklas 2010: 78-96 at 78-80, 845, with reference to LXX Jer 1:5; Isa 49:1.6 behind Gal 1:15-16, and to, among other passages, LXX Jer 7:25, 25:4 regarding $\delta$ oṽ $\lambda$ oc, and LXX Isa 52:7; Nah 2:1; Isa 40:9, 60:6,

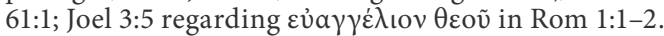

41 See Wilk 2005: 134-47 on 1Cor 1:17 / Isa 61:1 (“allusion”); 1 Cor 1:19 / Isa 29:14 ("quotation"); 1 Cor 1:20 / Isa 33:18b, 19:11-12, 44:25b (“allusions"); 1 Cor 2:16 / Isa 40:13 (“allusion"); 1 Cor 14:21 / Isa 28:11-12 (“quotation"); 1 Cor 14:25 / Isa 45:14 (“allusion”); 1 Cor 15:32 / Isa 22:13 (“allusion”); and 1 Cor 15:54 / Isa 25:8 (“quotation”). 


\subsection{Settings of early Christian prophecy in Paul's letters}

Prophetic speech is part of Paul's concerns from his earliest correspondence, his first letter to the Thessalonians, onwards. Thus, in 1 Thessalonians 5:1922, Paul includes the following advice in his concluding exhortation:

${ }^{19}$ Do not quench the Spirit, ${ }^{20}$ do not despise prophesying, ${ }^{21}$ but test everything; hold fast what is good, ${ }^{22}$ abstain from every form of evil (RSV).

This statement correlates the presence of the Spirit with the gift of prophesying, ${ }^{42}$ but also makes the critical point of testing everything. Analogously, prophecy and the ability to distinguish between spirits are consecutively coupled in 1 Cor 12:10 as complementary gifts, ${ }^{43}$ somehow as various kinds of tongues and the interpretation of tongues are coupled in the same verse. Further, 1Cor 14:29 correlates prophetic speech with weighing what is said.

Even though OT prophecy is distinct from early Christian prophecy in Paul's theology, the two may also be found correlated in his Letters. While scholarship is divided between maximal and minimal identifications of early Christian forms of prophetic speech in Paul's Letters, ${ }^{44} 1$ Cor 15:51-52 and Rom 11:25-26 are most recurrently identified as such. ${ }^{45}$ These passages respectively concern end-time visions regarding resurrection (1 Cor 15:51-

42 Cf. Sanders 2015: 185, 712. See also Donfried 2002: 193 on 1 Thess 5:19.20 as a differentiation "between the gospel as the word of God handed on by the church but made alive by the Spirit and prophetic utterance as a Spirit-driven revelation of hidden mysteries that is primarily concerned with the encouragement of God's people" (italics mine). Also this differentiation leaves the impression of partial correlation through the Spirit.

43 Cf. Fitzmyer 2008: 468 on comparison of 1 Cor 12:10 with the Didache 11.7-10 for discernment of spirits being applied to prophets, which may be interrelated but "should not be limited to prophets". See also Tibbs 2007: 207, "The "discernment of spirits" is closely related to prophecy, for both "spirits" and "prophecy" require testing".

44 Aune 1983: 248-262 identified early Christian oracles in 2 Cor 12:9; 1 Cor 15:51-52; Rom 11:25-26; 1 Thess 4:15-17; 1 Cor 12:3; 1 Cor 14:37-38; Gal 5:21b; 1 Thess 3:4; 1 Thess 4:2-6; (and 2Thess 3:6.10.12). Merklein [1992: 402-29] 1998: 377-404 studied 1 Thess 4:13-18, 1 Cor 15:50-58, 1 Cor 2:6-16 and Rom 11:25-36 as evidence of prophetic speech. In Luz 2010: 65, we find a reduced list of “three 'safe' traces of Christian prophecies”, contained in 1 Thess 4:16f., Rom 11:25b-26, and 1 Cor 15:51b-52.

45 Aune 1983: 250-3 and 325 on Rom 11:25-26, 1 Cor 15:51-52, and 1 Thess 4:16-17 as "eschatological theophany oracles"; Luz 2010: 65; Nicklas 2010: 94-8 rubricises 1 Cor 15:51 and Rom 11:25 among "mystery" as a figure of prophetic speech. 
52) and Israel's salvation (Rom 11:25-26). Both passages are surrounded by citations of biblical prophecy, both from the book of Isaiah, Isa 25:8 in 1 Cor 15:54, followed by Hos 13:14 in 1 Cor 15:55, and Isa 59:20-21a with Isa 27:9 in Rom 11:26-27. The revelation of a mystery which Paul voices in his eschatological visions with exegetical reference to biblical prophecy was not unknown to ancient Judaism. With regard to the Dead Sea Scrolls, the contemporizing exegesis of the prophets of old as a "prophetic experience" has been framed "revelatory exegesis" in a recent study by A.P. Jassen. ${ }^{46}$ In a way, early Christian prophecy as framed by Paul thus also rose from a Jewish soil.

Early Christian prophecy ranks prominently among Pauline lists of spiritual gifts, as we may infer from Rom 12:6-8 and from 1 Cor 12:28 as well as 14:1. When prophecy is mentioned as the first "gift according to the grace given to us" in Rom 12:6 (RSV), its character as a gift has been recurrently interpreted as inspired speech. ${ }^{47}$ Across the Pauline Letters, the functions of early Christian prophecy for the benefit of the faith community include the following aspects:

- related to the Spirit and to what is good (1 Thess 5:19-21)

- "in proportion to faith" (Rom 12:6);

- “for (people's) upbuilding, encouragement and consolation" (1 Cor 14:3);

- for learning and encouragement (1 Cor 14:31).

I will return to some of these homiletic functions, when considering sections in 1 Cor 12-14.

\section{Toward rereading 1 Corinthians $12-14$}

Turning to 1 Cor 12-14 for relevant passages on prophecy, it should be noted that this larger section has long been recognised as key evidence about early Christian prophecy. ${ }^{48}$ 1 Cor $12-14$ is delimited by Paul's

46 Jassen 2007: 203-7 and 2016: 353-72.

47 Dunn 1988: 727, "inspired speech, words given as from "without" (by the Spirit) and not consciously formulated by the mind"; Fitzmyer 1993: 647, "inspired Christian preaching".

48 Cf. Aune 1983: 13 on a study by D. Hill in 1979 on 1 Cor 12-14, Aune 1983: 190 on 1 Cor 12-14, Did. 10-13, and the Acts of the Apostles as three principal sources on early 
introductory formula $\pi \varepsilon \rho \grave{~} \delta \grave{\varepsilon} \tau \tilde{\omega} v \pi v \varepsilon v \mu \alpha \tau \iota \kappa \tilde{\omega} v$, "now about spiritual gifts", in 1 Cor 12:1, of which the reading as a neuter form may be validated by his subsequent exposition in 1 Cor 12:4-11 as well as the presumptive reference

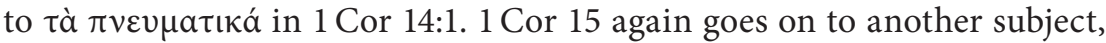
that of the resurrection. The literary unity of 1 Cor 12-14 as a larger section regarding divine gifts of the Spirit has recently been underscored by Soeng $\mathrm{Yu} \mathrm{Li}$, who considers prophecy as major paradigm in Paul's exposition on these gifts for a future-oriented faith community. ${ }^{49}$ At any rate, prophecy recurs throughout several passages in this larger section, as we will see.

At the same time, the subject of spiritual things ( $\pi v \varepsilon v \mu a \tau$ s $\alpha$ ) and divine

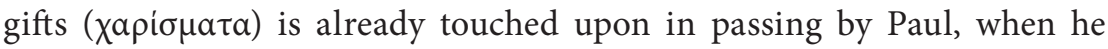
begins his Letter with a statement of thanksgiving (1 Cor 1:4-9), observing that his Corinthian audience is "not lacking in any spiritual gift, as you wait for the revealing of our Lord Jesus Christ" (1 Cor 1:7, RSV). Paul also mentions the interpretation of "spiritual truths to those who possess the Spirit" (1 Cor 2:13, RSV), when speaking about the secret and hidden wisdom of God (1 Cor 2:7). Yet the constraints which the apostle meets when corresponding with his Corinthian audience are disunity, dissensions and factionalism (1 Cor 1:10-17). This prevents Paul from addressing them as "spiritual people" and leaves them for the moment as people of flesh (1 Cor 3:1). ${ }^{50}$ Paul's consideration of spiritual things as a topic in 1Cor 12-14, with prophecy as especially prominent among divine gifts, aims to remedy disunity by stressing unity in the Spirit.

With this overall setting of 1 Cor 12-14 within 1 Corinthians at large in mind, I now discuss aspects of prophecy in 1 Cor 12:4-11, 13:8-13, 14:1-5, and 14:20-33a, with a view to contextual reading.

Christian prophecy; Forbes 1995: 1 on 1 Cor 12-14 as "our single most explicit source of information about early Christian prophecy"; see recently Li 2017.

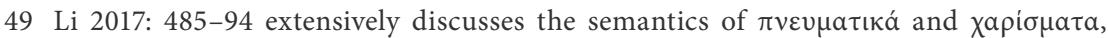
arguing for a meronymic relationship, thereby considering 1 Cor 12-14 as a larger

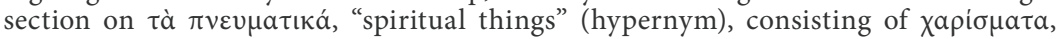

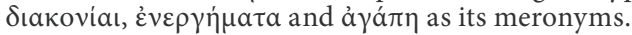

50 On the rhetorical situation of 1 Corinthians, see the discussion by Hogeterp 2006: 302-11. 


\subsection{Corinthians 12:4-11}

1 Cor 12,4-11 describes manifestations of the Spirit through a variety of gifts, including the utterance of wisdom, the utterance of knowledge, faith, gifts of healing, working of miracles, prophecy, the ability to distinguish between spirits, various kinds of tongues, and the interpretation of tongues (1 Cor 12:8-10). Throughout this variety of spiritual things and the variety of modalities (gifts, ministries, workings in 1 Cor 12:4-6), Paul stresses their service to the common good (1 Cor 12:7). In this passage, prophecy is embedded in a web of spiritual things and consecutively coupled with the ability to distinguish between spirits, a bit like tongues are coupled with the interpretation of tongues (1 Cor 12:10). ${ }^{51}$ This consecutive reference to prophecy and the discernment of spirits may imply a broader context of prophetic consciousness and its testing. ${ }^{52}$ It should further be noted that the spirits of prophets, $\pi v \varepsilon v \dot{\mu} \mu \tau \alpha \pi \rho \circ \varphi \eta \tau \tilde{\omega} v$, are eventually mentioned by Paul in 1 Cor 14:32, as part of an ultimate section on the weighing of what is said through prophecies (1 Cor 14:29-33), of which the spirits are subject to the prophets for clarity's sake, since prophecy concerns intelligible inspired speech. In fact, the papyrological commentary on 1 Corinthians by ArztGrabner underlines the general meaning of $\delta$ ı́́k

In a communal context, the discernment of spirits may find a formal analogy in the Dead Sea Scrolls, of which the Scrolls movement was also prophetically inspired and engaged in "revelatory exegesis". ${ }^{54}$ This formal analogy implies that the discernment of spirits was also an issue in certain, albeit sectarian, strands of Early Judaism which engaged in prophetic inspiration, so that Paul's point is not without parallel in a Jewish matrix of thought. That is, the examination and testing of spirits as well as deeds

51 See note 43 above. At any rate, within 1 Cor 12,4-11, prophecy and the discernment of spirits are integrally related to gifts of the Spirit $(1$ Cor 12,4$)$ as varieties or subspecies of individually apportioned forms of inspiration by the Spirit (1 Cor 12,11). In 1 Cor

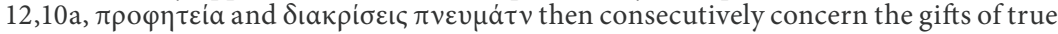
prophecy, when inspired by the Spirit, and the discernment of holy spirits as distinct from unholy or evil spirits, when inspired by the Spirit. Cf. Tibbs 2007: 207-213 and 271 , who concludes that the plural form "spirits" in 1 Cor 12:10, 14:12.32 each time refers to "holy spirits".

52 Cf. Thiselton 2000: 962-6.

53 Arzt-Grabner 2006: 415, "Untersuchung". Cf. Tibbs 2007: 208, who notes a "similar

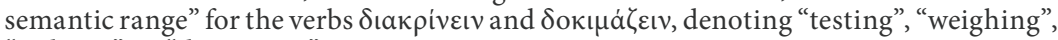
"judging" or "discerning".

54 Jassen 2007: 203-7 and 2016: 353-72. 
recurs in the Qumran Community Rule (1QS 5.20-21, 5.24, 6.17), ${ }^{55}$ where it serves a communal purpose of hierarchy and unity. This same text also mentions the authoritative role of an interpreter in finding out matters hidden from Israel (1QS 8.11-12) along with progressive revelations through God's holy Spirit from Moses and the prophets onwards ("from age to age", 1QS 8.15-16). With Paul, the testing or weighing of prophecy

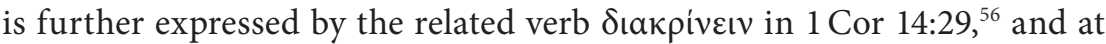
the outset, Paul has underlined the divide between pagan diversion and utterances by the Spirit of God (1 Cor 12:2-3). More generally speaking, the testing of prophecy in Paul also stands in relation to its Jewish heritage. ${ }^{57}$

In Paul, early Christian prophecy yet has a relatively more distinct and outspoken place: "the spirits of prophets are subject to prophets" (1 Cor

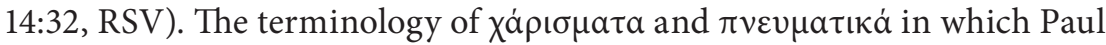
couches his references to prophecy as a gift further stands relatively apart from varieties of speech in the Corinthians' Greek environment. ${ }^{58}$ Yet his audience could have readily surmised their meaning from the context of Paul's exposition on gifts and the Spirit. In this connection, early Jewish literature, as represented by the Qumran text 4QInstruction, provides an interesting parallel concerning a "people of the Spirit" or "spiritual people" as opposed to a "spirit of flesh" (רוח עם) (בשר רוח), which "does not know the difference between [goo]d and evil according to the judgment of its [sp]irit" (4Q417 2 i 16-18). ${ }^{59}$ The concept of spiritual people as related to Israel would not have been unknown to Paul, since he writes elsewhere in Romans 15:27 that the Gentiles have come to share in the "spiritual

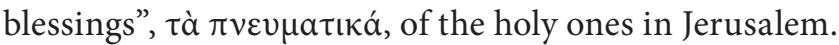

55 The verbs דרש (1QS 5.20, 6.17) and פקד (substantivized ptc. פוקדם, 1QS 5.24) have 'their spirits' (רוח) as object.

56 Cf. Dunn 1998: 556-7.

57 Cf. Cook 2011: 115-6.

58 Cf. Li 2017: 49-50, who only lists $4^{\text {th }}-8^{\text {th }}$ century C.E. Greek papyri for the use of $\chi \alpha \dot{\rho} \iota \sigma \mu \alpha$, noting that TLG references to $\chi \alpha \dot{\rho} \iota \sigma \mu \alpha$ "were not really helpful. The earliest reference mentioned by TLG is Philo followed by the Pauline texts". Li 2017: 106 notes something similar for the meaning of $\pi v \varepsilon v \mu a \tau$ เ ó $\varsigma$ as "of spirit, spiritual" in LSJ, which "refers to three written sources of which only one is non-biblical, namely Plutarch, Vitae Parallelae 2.129c; the other two references are from the corpus Paulinum (Rom 15:21 and 1 Cor 2:13)". Arzt-Grabner 2006: 132-3 notes that the adjective $\pi v \varepsilon v \mu a \tau$ เкó only occurs in documentary papyri of late antiquity $\left(4^{\text {th }}\right.$ c. C.E. $)$, which would rather illustrate Pauline influence ("Fortwirken der paulinischen Terminologie").

59 Translation from García Martínez and Tigchelaar 2000: 859. 


\subsection{Corinthians 13:8-13}

Our next passage, 1 Cor 13:8-13, pinpoints the limitations of prophecy from an eschatological perspective. Prophecy is here considered finite, it will pass away, and it only manifests itself in part (1 Cor 13:8-9). Prophetic knowledge could be perceived as being limited also in early Jewish thought, as illustrated by the Qumran Pesher to Habakkuk, which speaks of the final age being extended "beyond all that the prophets say" (1QpHab 7.7-8).

Paul compares the contemporaneous situation with seeing in a mirror dimly and knowing in part over against seeing face to face and gaining full understanding, being fully understood in the final age (1 Cor 13:12). Throughout chapter 13, Paul emphasizes that that which endures from the present to the final age is love. Without love, nothing is gained with prophetic powers (1 Cor 13:2). M. Wolter calls this the eschatological relativization of the gift of prophetic speech in Paul's theology. ${ }^{60}$

Yet the references to the finite and partial qualities of prophecy in 1 Cor 13:8-9 should not detract from the fact that Paul resumes his discourse

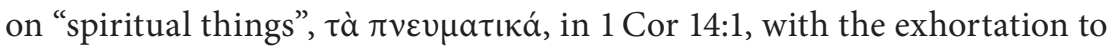
earnestly desire them, considering "prophecy" as special gift. The aim of love (1 Cor 14:1), heavily stipulated in 1 Cor 13, does not preclude eagerness for gifts of the Spirit, but in Paul's understanding should predetermine it. Li thus understands 1 Cor 13 as Pauline argument that "å $\gamma \alpha$ $\pi \eta$ is behaviour that seeks the benefit of others and not its own benefit," concluding that "the paradigm prophecy is characterized by à $\gamma \dot{\alpha} \pi \eta " .{ }^{61}$

Perhaps it should be added that prophecy is not so much relativized as its nature is put into perspective with regard to the final age. If the final age dissolves the distance between humankind and God, which Paul catches in the imagery of "seeing face to face, understanding fully, even as I have been fully understood", then the raison d'etre of prophecy as mediation of the word of God ends with the final age. Yet the notions of full understanding and face to face contact appear proleptically embodied in Paul's understanding of love. If the aim of love undergirds the desire of the special gift of prophecy then Paul has nothing against it, but even

60 Wolter 2011: 200; cf. Sanders 2015: 277.

61 Li 2017: 491 and 493. 
commends it in the interest of the upbuilding of the faith community, as we see in 1 Cor 14:1.

\subsection{Corinthians $14: 1-5$}

1 Cor 14:1-5 puts the distinction between prophecy and speaking in tongues, glossolalia, in sharp perspective. This distinction has already been foreshadowed by consecutive references to speaking in the tongues of men and of angels and to prophetic powers in 1 Cor 13:1-2. Speaking in tongues without love is associated with "a noisy gong or a clanging cymbal" in 1 Cor 13:1, whereas prophetic powers are surrounded by the understanding of all mysteries and all knowledge and all faith in 1 Cor 13:2, which yet amount to nothing without love. In 1 Cor 14:1-5, Paul addresses this distinction in increasing sharpness. Thus we read in 1 Cor 14:2-4:

${ }^{2}$ For one who speaks in a tongue speaks not to men but to God; for no one understands him, but he utters mysteries in the Spirit. ${ }^{3}$ On the other hand, he who prophesies speaks to men for their upbuilding and encouragement and consolation. ${ }^{4} \mathrm{He}$ who speaks in a tongue edifies himself, but he who prophesies edifies the church (RSV).

In 1 Cor 14:5, Paul adds that prophecy is greater than speaking in tongues. Both may be put in practice, but the latter is only for one's own benefit, unless it is followed by interpretation. Where does this distinction between prophecy and speaking in tongues come from?

Glossolalia vs. prophecy

Speaking in tongues is characterized as unintelligible to other people, whereas prophecy stands out for its intelligibility and moral outreach to the faith community in Paul's understanding in 1 Cor 14:1-5. In his study on prophecy and inspired speech, C. Forbes sought to dissociate alleged Hellenistic religious contexts of "ecstatic speech" from Paul's discussion of speaking in tongues. Forbes rather associated Pauline glossolalia with spiritual elitism among the Corinthians drawing on speculations within Jewish Hellenism. ${ }^{62}$ And yet the papyrological commentary by ArztGrabner notes the comparability of two aspects, that of cultic context and

62 Forbes 1995: 316-21. 
of foreign or strange speech. ${ }^{63}$ In this connection, $2^{\text {nd }}-3^{\text {rd }}$ century papyrus evidence of hymns being sung in a strange tongue in a cultic association of Apollo counts for Arzt-Grabner as a parallel in content. ${ }^{64}$ Yet a foreign language appears problematic as Pauline context, for speaking in tongues is variously complemented by "tongues of men and of angels" (1 Cor 13:1), "speaking to God" and "uttering mysteries in the Spirit" (1 Cor 14:2). Thus a spiritual sense should be included.

The fact that Paul does not specify where his idea of "speaking in tongues" comes from could imply its diffuse presence in various contexts. With "speaking in the tongues of men and of angels" (1 Cor 13:1) in mind, heavenly thanksgiving with angelic tongues which is evoked in the so-called Songs of the Sabbath Sacrifice from Masada (Mas1k) and Qumran (4Q400-402, 404-407, 11Q17) may constitute a parallel from Judaism. ${ }^{65} \mathrm{Jewish}$ Hellenism as represented by Philo illustrates experiences of divine inspiration and ecstasy. This manifests itself in unconsciousness of words spoken and lines written and at the same time relates to the reception of "language, ideas, an enjoyment of light, keenest vision, pellucid distinctiveness of objects" (Migr. 34-35). ${ }^{66}$ Finally, the pagan Greek environment of the Corinthian audience may further loom in the background, which Paul has at any rate brought to the attention in 1 Cor 12:2-3. That is, Greek religion knew a dichotomy between a "seer" ( $\mu \alpha \dot{v} \tau \iota \varsigma)$ and an explainer of utterances, the prophet. ${ }^{67}$ Different from a Jewish context, the Corinthian audience would then have been used to a distinction between oracular receptivity and interpretive proclamation, even if re-applied to an early Christian context.

In any case, Paul wants his Corinthian audience to stay away from unintelligible ecstatic utterances which are not guided by the Spirit (1 Cor $12: 1-3)$ and only commends speaking in tongues as inspired speech when it is accompanied by interpretation (1 Cor 12:10, 14:27-28).

63 Arzt-Grabner 2006: 407, “fremdes oder fremdartiges Sprechen”.

64 Arzt-Grabner, Ibid.

65 Mas1k 2.3-16 // 4Q403 1 i 1-6 // 4Q404 1 evoke psalms of singing by seven "chief princes", specifying the "tongue", בלשון, of each of these seven in the realm of God and his exalted angels.

66 Translation from J.R. Levison in Floyd and Haak 2006: 197.

67 Burkert 1985: 112. 


\section{Homiletic functions of prophecy}

As for the homiletic functions of prophecy, Paul specifies them in 1 Cor

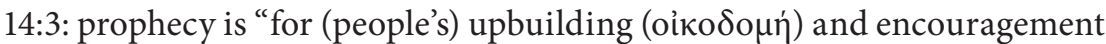

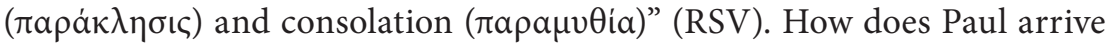
at assigning these homiletic functions?

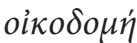

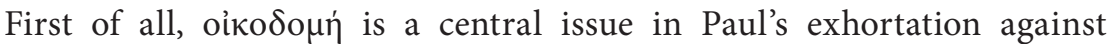
dissension and for communal upbuilding. In fact, the Corinthian audience has been addressed as God's building in 1 Cor 3:9. Paul here sets out to assign a constructive role to prophecy, beginning with the faith community's upbuilding. Analogously, upbuilding would also be part of prophetic roles of a "prophet in the womb" according to Sirach $49.7 .{ }^{68}$

$\pi \alpha \rho \alpha \dot{\kappa} \lambda \eta \sigma \iota \varsigma$

Next, Paul refers to $\pi \alpha \rho \alpha \dot{\kappa} \lambda \eta \sigma \iota \varsigma$, which may mean both encouragement and exhortation. According to Acts 13:15, a word of exhortation or encouragement ( $\lambda$ ó $о \varsigma \pi \alpha \rho \alpha \kappa \lambda \dot{\sigma \varepsilon \omega \varsigma}$ ) is also expected in a homiletic synagogal setting after readings from the Law and the Prophets.

$\pi \alpha \rho \alpha \mu v \theta i \alpha$

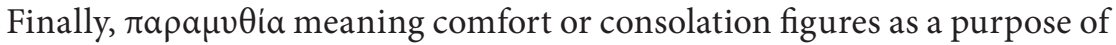
prophetic speech. Next to Isaiah, Jeremiah and the twelve Minor Prophets, post-70 C.E. Jewish literature has been noted in previous scholarship regarding "prophets as proclaimers of consolation". ${ }^{69}$ It may be added that prophecy was also understood as "words of consolation", תנחומים, in 4QTanhûmîm (4Q176 1-2 i 4), where it introduces citations of Isa 40:1-5 and 48:1-9. 2 Maccabees 15.9 further mentions consolation from the Law and

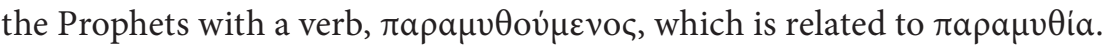

68 LXX Sir 49.7 enumerates prophetic roles of Jeremiah, starting with deconstructive roles "to uproot and to ruin and to destroy", and then turning to constructive roles "to build and to plant". Yet this concerns the context of Babylonian devastation, exile and return. The figures of building and planting also occur in 1 Cor 3:6-9.

69 Sandnes 1991: 39-41. 


\subsection{Corinthians 14:20-33a}

The last passage under our consideration is 1 Cor $14: 20-33 a .{ }^{70}$ In 1 Cor 14:21-22, Paul quotes Isaiah 28:11-12 to argue that tongues are a sign for unbelievers, whereas prophecy is for believers. It has been argued by F. Wilk that Paul's discourse in 1 Cor 14:20-25 reflects a broader reading of Isaiah 28:7-10.11-12, echoing “an Isaianic invective against Israel's authorities who, going into ecstasies and talking like infants, failed in their duty to teach". ${ }^{71}$ It should be added that these authorities are identified as priest and prophet in both the Hebrew Bible (MT Isa 28:7) and the Septuagint (LXX Isa 28:7). Under wrong influences, they have gone astray and their counsel has become void. Perhaps Paul's distinction between speaking in tongues and prophecy may here intertextually denote a contrast between ecstatic, distorted forms of prophetic inspiration and pure mediation of prophecy. Paul even goes so far that speaking in tongues would give the impression of madness to outsiders and unbelievers (1 Cor 14:23). Perhaps the intertextual dialogue with Isaiah 28:7-10.11-12 ultimately also conveys a thinly veiled warning against misguided inspiration and ecstatic speech, which find themselves on the road to false prophecy.

When Paul goes on to discuss prophecy and other spiritual matters in 1 Cor 14:24-33a, he makes general references to prophecy: "if all prophesy" (1 Cor 14:24) and "you can all prophesy one by one" (1 Cor 14:31). Which generalization of prophecy could be at work?

Two examples from Jewish Hellenism may illustrate generalising tendencies of thought about prophecy:

1. The Wisdom of Solomon 7.27, speaking figuratively about wisdom, states that "in every generation she passes into holy souls and makes them friends of God and prophets" (RSV).

\footnotetext{
70 It is beyond the scope of this essay to consider 1 Cor $14: 33 \mathrm{~b}-36$, on which cf. Thiselton 2000: 1146-62 regarding its complex literary status (Pauline or un-Pauline) and polyvalent interpretation, which could constitute the subject of another essay by itself. The concluding statement in 1Cor 14:37-40 recapitulates, reminding the reader of similar statements in 1 Cor 11:16 and 1 Cor 14:1.5.
}

71 Wilk 2005: 141-3 at 143. 
2. In his treatise Who is the Heir of Divine Things (Her. 259), ${ }^{72}$ Philo writes

... and the sacred scriptures testify in the case of every good man, that he is a prophet; for a prophet says nothing of his own, but everything which he says is strange and prompted by some one else; and it is not lawful for a wicked man to be an interpreter of God ( $\dot{\varepsilon} \mu \eta \nu \varepsilon \dot{v} \varsigma \theta \varepsilon o \tilde{u})$, as also no wicked man can be properly said to be inspired; but this statement is only appropriate to the wise man alone, since he alone is a sounding instrument of God's voice

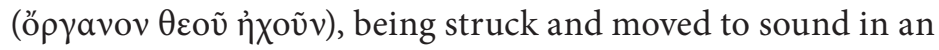
invisible manner by him.

The prophetic state is deemed generally reconcilable with holy souls and friends of God in Wis 7.27 and with every good person in Philo's thought. In Paul's view, prophecy is reconcilable with the community of the faithful, calling even the outsider or unbeliever to worship of God, to acknowledgement of God's presence (1 Cor 14:24-25).

\section{Evaluation and conclusions}

It is time to draw a balance and come to conclusions. Paul's Letters are the earliest documents of emerging Christianity, and also provide the earliest evidence of Christian prophecy.

How does Paul stand between the alleged "cessation of prophecy" in Judaism and prolific early Christian prophetism? As I have argued in this essay, it is not so much a matter of "cessation of prophecy" as a cessation of the line of biblical prophets. Paul also distinguished the prophets of the Holy Scriptures (Rom 1:2) from his ideas about early Christian prophecy. Yet prophecy as a revelatory phenomenon had not ceased in the Second Temple period. Even if it were in decline in the early post-exilic period, it went through a transition.

Illuminating worlds of thought in late Second Temple Judaism, the Dead Sea Scrolls provide clear indications of the heightened significance of biblical prophecy as well as contemporizing, eschatologically oriented exegesis

72 Translation from Yonge at www.earlyjewishwritings.com/philo.html. 
of prophecy. The abundance of parabiblical elaborations on prophetic texts among the Scrolls attests to an open dialogue with prophecy. The eschatological fervour of emerging Christianity also brought prophetic inspiration to the fore. In his Corinthian correspondence, Paul sees early Christian prophecy as an active and constructive force in the upbuilding of the faith community at Corinth.

As for the second question which this essay aimed to answer, the sense of "prophecy" which Paul has in mind in 1Cor 12-14, I conclude that its homiletic functions of upbuilding, encouragement and consolation may be partly correlated in broad lines with early Jewish tradition and synagogue settings, as illustrated in Acts 13:15. Early Christian prophetic speech as identified in Romans 11:25-26, regarding Israel's salvation, and in 1 Cor 15:51-52, regarding resurrection, is also intertextually correlated with biblical prophecy by Paul, as we have seen. Early Christian prophecy thereby builds on biblical models of prophecy and early Jewish contexts of prophecy.

As for the third question what prophetic performance does in the communal setting of 1 Cor $12-14$, it is destined to contribute to the upbuilding and peace of the faith community (1 Cor 14:4-5.33; cf. Acts 9:31). When the faith community is united in prophecy, it ultimately also reaches out to the unbeliever or outsider in Paul's view (1 Cor 14:24-25).

\section{Select bibliography}

Arzt-Grabner, P., et al. (2006) 1. Korinther (PKNT, 2), Göttingen, Vandenhoeck \& Ruprecht.

Ash, J.L. (1976) “The Decline of Ecstatic Prophecy in the Early Church", TS 37: 227-52.

Aune, D.E. (1983) Prophecy in Early Christianity and the Ancient Mediterranean World, Grand Rapids, Eerdmans.

Barrett, C.K. (1968) A Commentary on the First Epistle to the Corinthians, London, A\&C Black. 
Brooke, G.J. (2006) "Prophecy and Prophets in the Dead Sea Scrolls: Looking Backwards and Forwards", in Floyd and Haak (eds.), Prophets, Prophecy, and Prophetic Texts in Second Temple Judaism, 151-65.

Burkert, W. (1985) Greek Religion, English translation by J. Raffan from German original in 1977, Cambridge, Mass., Harvard University Press.

Conzelmann, H. (1975) 1 Corinthians. A Commentary on the First Epistle to the Corinthians Translated by James W. Leitch (Hermeneia - A Critical and Historical Commentary on the Bible), Philadelphia, Fortress Press.

Cook, L.S. (2011) On the Question of the "Cessation of Prophecy" in Ancient Judaism (TSAJ, 145), Tübingen, Mohr Siebeck, 2011.

De Jong, M. (2007) Isaiah among the Ancient Near Eastern Prophets: A Comparative Study of the Earliest Stages of the Isaiah Tradition and the Neo-Assyrian Prophecies (VTSup, 117), Leiden, Brill.

Donfried, K.P. (2002) Paul, Thessalonica, and Early Christianity, London, T\&T Clark - Continuum.

Dunn, J.D.G. (1988) Romans 9-16 (WBC, 38B), Nashville, Thomas Nelson Publishers.

- (1998) The Theology of Paul the Apostle, London and New York, T\&T Clark - Continuum.

Fee, G.D. (2014) The First Epistle to the Corinthians. Revised Edition (NICNT), Grand Rapids, Mich., Eerdmans.

Feldman, L.H. [1990] (2006) "Prophets and Prophecy in Josephus". In Floyd and Haak (eds.), Prophets, Prophecy, and Prophetic Texts in Second Temple Judaism, [JTS 41: 386-422] 210-39.

Fitzmyer, J.A. (1993) Romans. A New Translation with Introduction and Commentary (AB, 33), New Haven, Yale University Press.

- (2008) First Corinthians. A New Translation with Introduction and Commentary (The Anchor Yale Bible), New Haven, Yale University Press. 
Floyd, M., and R.D. Haak, eds. (2006) Prophets, Prophecy, and Prophetic Texts in Second Temple Judaism (LOTS, 427), New York, T\&T Clark International.

Floyd, M. (2006). “Introduction.” In: Floyd and Haak (eds.). Prophets, Prophecy, and Prophetic Texts in Second Temple Judaism, 1-25.

Forbes, C. (1995) Prophecy and Inspired Speech in Early Christianity and in its Hellenistic Environment (WUNT, II/75), Tübingen, Mohr Siebeck.

García Martínez, F., and E.J.C. Tigchelaar (2000) The Dead Sea Scrolls Study Edition. 1. (1Q1-4Q273). 2. (4Q274-11Q31), Leiden, Brill Grand Rapids, Mich., Eerdmans.

Hogeterp, A.L.A. (2006) Paul and God's Temple: A Historical Interpretation of Cultic Imagery in the Corinthian Correspondence (BiTS, 2), Leuven, Peeters.

Jassen, A.P. (2007) Mediating the Divine: Prophecy and Revelation in the Dead Sea Scrolls and Second Temple Judaism (STDJ, 68), Leiden, Brill.

- (2006) “The Prophets in the Dead Sea Scrolls", in Sharp (ed.), The Oxford Handbook of the Prophets, 353-72.

Klijn, A.F.J. (1983) "2 (Syriac Apocalypse of) Baruch", in J.H.

Charlesworth (ed.), The Old Testament Pseudepigrapha. 1. Apocalyptic Literature and Testaments (ABRL), New York, Doubleday, 615-52.

Lange, A. (2005) "Reading the Decline of Prophecy", in K. De Troyer and A. Lange (eds.), Reading the Present in the Qumran Library: The Perception of the Contemporary by Means of Scriptural Interpretations (SBLSymS, 30), Atlanta, SBL, 181-91.

Levinskaya (1996) I., The Book of Acts in Its Diaspora Setting (The Book of Acts in Its First Century Setting, 5), Grand Rapids, Eerdmans Carlisle, Paternoster.

Li, S.Y. (2017) Paul's teaching on the Pneumatika in 1 Corinthians 12-14. Prophecy as the Paradigm of ta Charismata ta meizona for the FutureOriented Ekklēsia (WUNT, II/455), Tübingen, Mohr Siebeck. 
Luz, U. (2010) "Stages of Early Christian Prophetism", in Verheyden et al. (eds.), Prophets and Prophecy in Jewish and Early Christian Literature, $57-75$.

Merklein, H. (1998) "Der Theologe als Prophet. Zur Funktion prophetischen Redens im theologischen Diskurs des Paulus", in Id., Studien zu Jesus und Paulus II (WUNT, 105), Tübingen, Mohr Siebeck, [NTS 38 (1992) 402-29] 377-404.

Nicklas, T. (2010) "Paulus - der Apostel als Prophet", in Verheyden et al. (eds.), Prophets and Prophecy in Jewish and Early Christian Literature, 77-104.

Nissinen, M. (2016) "Prophetic Intermediation in the Ancient Near East", in Sharp (ed.), The Oxford Handbook of the Prophets, 5-22.

Perkins, P. (2012) First Corinthians (Paideia Commentaries on the New Testament), Grand Rapids, Mich., Baker Academic.

Sanders, E.P. (2015) Paul: The Apostle's Life, Letters, and Thought, Augsburg Fortress Press.

Sandnes, K.O. (1991) Paul - One of the Prophets? A Contribution to the Apostle's Self-Understanding (WUNT, II/43), Tübingen, Mohr Siebeck.

Schnelle, U. (2005) Apostle Paul: His Life and Theology (ET by M.E.

Boring of Paulus: Leben und Denken, Berlin, de Gruyter, 2003), Grand Rapids, Mich., Baker Academic.

Schniedewind, W. (1995) The Word of God in Transition: From Prophet to Exegete in the Second Temple Period, Sheffield, Academic Press.

Sharp, C.J., ed. (2016) The Oxford Handbook of the Prophets, Oxford, University Press.

Stökl, J. (2012) Prophecy in the Ancient Near East. A Philological and Sociological Comparison (Culture and history of the ancient Near East, 56), Leiden, Brill.

Thiselton, A.C. (2000) The First Epistle to the Corinthians (NIGTC), Grand Rapids, Eerdmans - Carlisle, Paternoster. 
Tibbs, C. (2007) Religious Experience of the Pneuma. Communication with the Spirit World in 1 Corinthians 12 and 14 (WUNT, II/230), Tübingen, Mohr Siebeck.

Verheyden, J. et al., eds. (2010), Prophets and Prophecy in Jewish and Early Christian Literature (WUNT, II/286), Tübingen, Mohr Siebeck.

Weippert, M. (2014) Götterwort in Menschenmund: Studien zur Prophetie in Assyrien, Israel und Juda (FRLANT, 252), Göttingen, Vandenhoeck \& Ruprecht.

Wilk, F. (1998) Die Bedeutung des Jesajabuches für Paulus (FRLANT, 179), Göttingen, Vandenhoeck \& Ruprecht.

- (2005) "Isaiah in 1 and 2 Corinthians", in S. Moyise and M.J.J. Menken (eds.), Isaiah in the New Testament (The New Testament and the Scriptures of Israel), London and New York, T\&T Clark International - Continuum, 133-58.

Wolter, M. (2011) Paulus: ein Grundriss seiner Theologie, NeukirchenVluyn, Neukirchener Verlag. 